\title{
My Little Box, Oh My Little Box... A Video-Netnographic Study On The Expression Of Values In Subscription-Based E-Commerce
}

\author{
Mohamed Slim Ben Mimoun, SKEMA Business School - Université de Lille, France
} Marion Garnier, SKEMA Business School - Université de Lille, France

Delphine Depledt, SKEMA Business School, France

\begin{abstract}
This paper focuses on the consumption experience of a cosmetics box issued from subscriptionbased e-commerce. On the basis of a netnographic analysis of videos and comments on YouTube, we highlight that the value typology developed by Holbrook (1999) applies to that new form of ecommerce and consumption experience.
\end{abstract}

Keywords: Values; Subscription-Based E-Commerce; Beauty Box; Netnography

\section{INTRODUCTION}

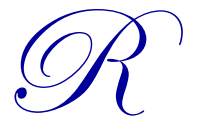

esearch in Consumer Behavior shows the importance of consumption experience (Holbrook \& Hirschman, 1982; Holt, 1995, Holbrook, 1999; Cottet et al., 2006). If even some experiential strategies success, some others may be disappointing (Kozinets et al., 2002). Promises of experience are hard to keep as offer become commonplace. In this research, we focus our interest on a new form of consumption that is mainly based on an experiential promise: the phenomenon of subscription-based e-commerce (boxes). Since 2010, boxes are indeed developing in a lightning way. After targeting fashion and cosmetics markets, it nowadays reaches all online sales areas with a personalized and discover-oriented offer. Web 2.0 tools led this activity to spread out consumers' enthusiasm. Indeed, consumers that adopt subscription-based e-commerce do not only live their consumption experience by themselves but share their experience through the display of videos on social networks sites.

The aim of this research is then to analyze the consumption experience that is lived and shared by several subscribers of My Little Box, a subscription-based e-commerce brand. This exploratory research adopts a netnographic approach (Kozinets, 1997, 2002, 2010), conducted over 5 months on YouTube within the community of beauty-fan consumers. This research aims at developing academic knowledge on consumer behavior in that specific context and giving firms insights on key strategic consumption outcomes. The main contribution lay in the identification of the Holbrook (1999)'s consumption value typology in the experiential consumption of boxes and to draw outcomes from this result. This paper will then first deal with the conceptual framework regarding subscription-based e-commerce stakes and e-word-of-mouth in virtual communities. The methodology, sample and analysis method are discussed. Finally, our results focus on the experience values that consumers express though eWOM on YouTube. 


\section{CONCEPTUAL FRAMEWORK}

\section{Subscription-Based E-Commerce}

Subscription-based e-commerce relies on receiving at home, relay shops or sales points, one or several products on a specific theme, with a predetermined pace and set price. It relates to convenience-based products, i.e. daily products that can be bought at a "discovering" or attractive price. The main principle of subscription-based ecommerce is curation (Rosenbaum, 2009): consumers receive products selected by an expert and that fit tastes and expectations previously declared in a questionnaire. Beyond satisfaction of a personalized need, consumers are waiting for original and unexpected products they wouldn't have thought about nor dared purchasing. This is why subscription-based e-commerce uses tryvertising (Mumaw, 2011), the ability to make people discover new products, usually through a sample size, and to make them try the product before purchasing it. The efficacy of such a technique is usually proportional to consumer involvement in the product category. Finally, beyond curation and tryvertising, subscription-based e-commerce also relies on event sales, as the offer is usually available for a limited period of time.

Furthermore, subscription e-commerce also relies on surprise (Vanhamme \& Dick, 2003) of the content that is an experience bonus. Indeed, some merchants do not disclose their offer, while some others may send a preselection of the content. Those mystery-boxes particularly fit products associated with pleasure (wine, gadgets) or well-being (cosmetics). Surprise participates in transforming the consumption moment into an unforgettable moment that is extraordinary, memorable and satisfying (Vanhamme \& Dick, 2003).

\section{Electronic Word-Of-Mouth (E-WOM) And Virtual Communities}

It is notable to state that joining a "surprise subscription" has no equivalent in traditional commerce. Though, the attractiveness of this novelty does not necessarily mean a taste for the unknown. This is why before any subscription consumers are usually looking for information that may be available on social networks and given by other consumers displaying the content of their parcels on their blog or YouTube channel. Announcers have understood that the opinion of those expert consumers, that may be well-known in the target community, can get more credit than any other advertising. Research showed eWOM to be a significant power that influences consumer behavior (Bickart \& Schindler, 2001; Ratchford et al., 2003) and specifically affects consumer loyalty and purchase decisions (Fong \& Burton, 2008; Khammash, \& Griffiths, 2011). This is why they first sent boxes to web influencers that took in charge a free promotion.

The idea of completing a consumption experience by a social experience is one of the key of subscriptionbased e-commerce in order to favor positive e-WOM on social networks. Indeed, contrary to traditional WOM, eWOM (positive or negative) has unequal rapidness and reach. Using Web 2.0 technologies such as online forums, newsletters, information groups, social networks and blogs highly facilitates interactions between individuals (Goldsmith, 2006). Furthermore, online recommendations are more easily accessible to consumers, more persisting over time and more measurable than traditional offline WOM (Lee et al., 2008)

In our study, we focus on a specific expression form used by consumers to talk to other consumers: the product video review. When filmed while opening the parcel, it is named "unboxing" or "unpacking". This method was originally used by a technology-passionate audience and was taken up especially by the beauty community to show and praise the benefits of cosmetics products - for which demonstration is important as the product is involving. Those videos act as a kind of product sheet, more or less detailed and subjective, but considered as honest regarding other consumers. So e-merchants in the box market have soon understood the stakes of creating a community around their service. Doing so, they intend to create an affective relationship with their clients and to communicate on their values. The idea is to become a "real" brand and not only a service that intermediates the relationship between distributed brands and the consumer.

We are then going to focus on how subscribers communicate online about the My Little Box offer and more particularly on how those consumers share their experience, to understand how it may participate to perception and value of subscription-based e-commerce. 


\section{METHODOLOGY}

\section{Netnography As A Methodology}

Netnography, as a qualitative method, is based on the participative (or not) observation of community members in their environment (Kozinets, 1997, 2010, 2002). It is particularly adapted to the study of subscriptionbased e-commerce, as it is a new and complex phenomenon. A study conducted with netnography is composed of several steps: formulation of a research question, choice of the community to study, data collection techniques and results analysis and interpretation. Netnog raphy necessitates the researcher to be immerged within the observed environment, the way members of the community are (Kizonets, 1997). It intends giving a meaning to communication acts of this community "(...) the goal being to enlight a marketing problematics linked with the marketing objects and not the community in itself" (Bernard, 2004). Immersion in the community, as the ethnographer is doing in observed tribes, allows the researcher to get familiar with the culture of the community.

\section{Selection OF THE COMMUNITY}

Netnography then relies on virtual consumption communities as source of data. The choice of the community is then crucial. To identify it, we first realized a search on Google to find websites and forums dealing with the topic of boxes on the Internet. We identified a forum - http://beautybox.forumactif.fr - with more than 730 active members out of 950 registered participants at the moment of the data collection (Dec. 2012).

This forum allows consumers of beauty subscriptions to discover new offers, present the content of boxes they have received (with a defined "spoiler rule") and give their opinion on firms proposing those offers. This community also exchanges on social media such as Facebook, Youtube, Hellocotton and on blogs. It is not only "virtual" as events are organized between members to meet or exchange boxes "in real life". It is interesting to indicate that this forum is also opened to discussions on subscriptions for other products: part of the forum is dedicated to other boxes (cooking, wine, tea, lingerie... with 83 topics and 8369 answers at the time of the study). We can then talk about a community of boxes fans, an open community that allows nomadic participation and creates numerous contacts, in which individual may belong to several communities at the same time.

\section{Our STUDY: My Little Box CASE}

As stated previously, beauty boxes were the most popular and among them My Little Box (MLB) was a leading box gathering numerous reviews and comments. Also, the forum allowed us to identify that videos were the privileged way for consumers to review and express about beauty boxes. The choice was then made to focus on video reviews published on Youtube specifically concerning MLB.

Eight female consumers, newly or regular subscribers, that had made one or several product reviews of the MLB offer on YouTube were selected to be observed during 5 months and a half (between August and December 2012). Nevertheless, previous videos and comments were also visualized and analyzed to assess dynamics of the experience over time. A fair notes jotting down allowed to record behaviors and ideas that were progressively associated. In order not to influence the behavior of Internet users, no direct intervention occurred and no information about the study was communicated.

The choice was made to focus on very different profiles, new clients as well as very loyal consumers, with beginners on Youtube while others already have more than 20000 fans. Profiles of the observed consumers were the following (as of Dec. 2012): 
Table 1. Studied Youtubers' Profiles

\begin{tabular}{|c|c|c|c|c|c|c|c|c|}
\hline $\begin{array}{l}\text { YouTuber } \\
\text { (YTB) } \mathbf{N}^{\circ 1}\end{array}$ & $\begin{array}{l}\text { Creation Of } \\
\text { The Channel }\end{array}$ & $\begin{array}{c}\text { N. Of } \\
\text { Subscribing } \\
\text { Followers }\end{array}$ & $\begin{array}{l}\text { Ttl No Of } \\
\text { Videos }\end{array}$ & $\begin{array}{c}\text { N. Of Videos } \\
\text { About MLB }\end{array}$ & $\begin{array}{l}\text { 1st Video } \\
\text { About MLB }\end{array}$ & $\begin{array}{l}\text { N. Of Videos } \\
\text { About Other } \\
\text { Beauty Boxes }\end{array}$ & $\begin{array}{c}\text { N. Of Videos } \\
\text { About Non- } \\
\text { Beauty Boxes }\end{array}$ & $\begin{array}{c}\text { Presence On } \\
\text { Other } \\
\text { Networks }\end{array}$ \\
\hline 1 & $02 / 06 / 10$ & 1014 & 149 & 5 & $03 / 12$ & 4 & 0 & \\
\hline 2 & 09/05/11 & 20747 & 205 & 4 & $06 / 12$ & 19 & 5 & $\mathrm{x}$ \\
\hline 3 & 29/09/11 & 10048 & 30 & 2 & 09/12 & 2 & 0 & $\mathrm{x}$ \\
\hline 4 & $29 / 09 / 11$ & 5306 & 123 & 8 & $01 / 12$ & 2 & 0 & $\mathrm{x}$ \\
\hline 5 & $05 / 02 / 12$ & 919 & 133 & 5 & $06 / 12$ & 2 & 0 & \\
\hline 6 & $02 / 05 / 12$ & 508 & 51 & 1 & $12 / 12$ & 13 & 0 & \\
\hline 7 & $11 / 09 / 12$ & 684 & 21 & 3 & $09 / 12$ & 2 & 0 & $\mathrm{x}$ \\
\hline 8 & $05 / 11 / 12$ & 110 & 16 & 4 & $10 / 12$ & 2 & 0 & \\
\hline
\end{tabular}

YouTubers' videos usually last between six and twenty minutes. In total, 85 videos were used in this study: 32 relate to MLB and 53 are reviews for other boxes published by our eight Beauty YouTubers. The 32 videos' contents were transcribed in the lexicographic analysis tool NVivo in order to be analyzed and especially to analyze emotions, expressions and gestures within the videos. Comments linked to MLB videos were also transcribed in NVivo and analyzed. This corresponds to 1026 comments published by 472 subscribers ( 464 followers identified by their pseudonyms plus the 8 studied YouTubers). 92 of those subscribers left more than one comment, their others only commenting once. Remaining comments were those published as answers by YouTube channels' owners.

\section{Comments On The Sample}

We first find out profiles that were identified by Kozinets (1999): "fanatics", "initiates", "tourists" and "socials". "Tourists" are passing-by visitors with no specific link with other members and who watch videos by curiosity. In total, the 32 videos had 64723 views but only 1026 comments, meaning that $98.4 \%$ of watchers didn't post any comment. Among the 472 persons that posted a comment, the "socials" favor interaction with other members but display a superficial relationship with the consumption object: "I thank you to make me discover this box that I didn't know at all. And you receive one per month? Kisses, it's wonderful what you're doing, go along!!:)" (D.). As for "Fanatics", they develop a strong interest for the consumption but they do not necessarily look for sharing. As such, we stated that a great majority of participants that posted comments only did it once, be it on the YouTubers' channel or on several channels. We counted 97 individuals (19.8\%) that posted more than two comments. They are usually the YouTubers creating videos that answer to each comment posted on their channel. We can then categorize those members under the term of "initiates", as they develop a strong interest in the consumption and the community. Those individuals are very loyal to the media because they publish several videos per month.

\section{RESULTS AND DISCUSSION: SUBSCRIPTION-BASED E-COMMERCE AND EXPERIENCE VALUE}

Analysis of the content of videos and comments on YouTube allow stating the expression of the different forms of client value identified by Holbrook (1999).

\section{Values In Consumption}

Indeed, the consumption of a service that gives a direct access to cosmetics products, as in our study, relates to an experiential consumption, i.e. "a subjective state of awareness, along a variety of symbolic significations, hedonic responses and aesthetic criteria" (Holbrook \& Hirschman, 1982). The analysis of the perceived value can then be a way to understand the evaluation of the experience by the individual.

More precisely, perceived value is a "preferential, interactive, relative, personal and situation experience" (Holbrook, 1999). Preference comes from the existence of an evaluative judgement. Value is interactive because it rises from an interaction between the subject and the object that will be different from the characteristics of the

\footnotetext{
${ }^{1}$ Ethics considerations relate to that method, especially regarding the respect for private life of observed participants. This is why we replaced the pseudonym of YouTubers by a code number.
} 
object and the individual. It is relative because value is comparative between several objects, personal because depending on each individual, and situational as value is influenced by the consumption context.

Holbrook (1999) identifies three criteria that differentiate (value) preference judgment types. The value of a product can be extrinsic (a mean to reach other personal or social goals) or intrinsic (the object in itself is a source of gratification); self-oriented or other-oriented (that helps creating a social link). Finally, the fact that the consumer is active (action on the object) or passive will induce differences in the perceived value. Those three criteria lead to identify eight types of values from the client's point-of-view (Holbrook, 1999): efficiency, play, excellence, aesthetics, status, ethics, esteem and spirituality. We now present in what follows the relationship between each kind of value and the consumption experience of MLB shared on YouTube.

\section{Extrinsic Values}

The first motivation that makes a YouTuber posting a video review of her box is officially sharing information and the desire to be useful, an approach that is objective, rational and that makes her being considered as an expert and get that "status": "Hello! I would like to subscribe to a beauty box but I don't know which one, could you give me some advice? :)" (H.). The YouTuber is then a mediator between the brand and the consumer. She claims her expert status and plays that role: "I'll make you a review when I test the products." (YTB5). Individuals commenting give her this status and her recommendations are listened, solicited and thanked. The YouTuber is a distance-demonstrator that inspects attributes of all products in the box for a consumer that is willing not to make a mistake. This is especially the case with experience products like cosmetics for which knowledge is empirical. By transmitting her expertise, she makes consumers gaining "efficiency" as well as saving time and money: "Thank you so much for making that video because I wanted to buy a little box but now not anymore. Thank you again, you made me save a lot of money :)" (TLC).

The influence of the YouTuber and her recognition not only come from her expertise but also from her performance. Indeed, as a public character (being revealed facing the camera), she can get personal compliments as much as on the video content. She gets complimented on her appearance ("You are beautiful", "You've got thinner") or on her way to express herself. She then tends to professionalize videos by using television codes and norms (editing, credits, directed lights). Though her performance, the YouTuber may look for a certain "esteem" and recognition need, her self-expression being amplified by the personalized box content: "I felt like giving my opinion but it's only my opinion", "I got a product that everyone didn't get..." (YTB4). The initiate YouTuber organizes her emotions and knowledge through a narrative form that makes up for the consumption experience through space and time. This storytelling of the consumption act conveys values through which the YouTuber build the image she wants to convey of herself.

Furthermore, each experience is composed of a hedonic and a utilitarian dimension (Babin et al., 1994; Michon \& Chebat, 2004). The condition for a hedonic product to give pleasure is that it also fulfills consumer's utilitarian needs: "I'm really pleased by beauty products I'm going to use them all. For the moment I think they are doing better and better with that lifestyle box, so I'm really happy happy happy with this month's box." (YTB7). Indeed, even if there is no direct human intervention in subscription-based e-commerce, this model relies on curation and then supposes an expert selecting products to better adapt them to clients. So beyond the good deal, the core offer must be perceived as personalized and matching the individual's specificities: "I'm happy because My Little Box really listens to what we tell them in the beauty questionnaire about dry skin. I told I had dry hair and skin and they send me products for dry skin. They listen to what we say. It's very pleasing to be listened and to see they're reactive." (YTB1). The quality of MLB offer is highlighted here by the YouTuber: "My Little Box... far better than the others! I unsubscribed from all other boxes and I did well because sincerely, now, I'm paying $13 €$ and I know I receive the product... I don't know if you've seen we have 1, 2, 3, 4, 5, 6 products! We don't have those so-said samples (...). You have full size, a nice bag that is offered, 100\% natural, very beautiful. I feel like saying: unsubscribe from others and come to My Little Box. Well, it's my opinion." (YTB4). But to the contrary, a product that does not fit is source of disappointment: "Then, I had the flop of the box. This is the first time I receive one, but well, I've already seen videos... so I know it's a recurring problem in boxes. It's an extra-firming body care and I think that at 23 years-old, I don't need that". (YTB5). If failing, this is arousing suffering and anger: "Against, against, and against this new concept, oceans of paper and 2 products that are worth $1.82 €$ (...) I felt like being a 
big sucker!!!! lol" (SA). We noticed several references to cost, especially in disappointing episodes. So, searching not only for quality but even "excellence", MLB succeed in transmitting a peripheral offer that is composed of aesthetic and humoristic editorial supports, as well as gifts creating interactivity and favoring self-esteem. This is as a sales agent could do in a shop, and even more as suggested in the following testimony opposing the box and the shop experience - seen as frustrating: "When you're a girl and you're ordering a beauty box, what we want is that the pleasure is coming to us, that it is a moment alone that is pleasurable without anyone pissing you off. In a shop, you get mugged to be asked "Do you want anything?" Here, you get the surprise, it's our girlish moment and that's super personalized in the sense that there is an enormous work with all little sheets, packaging, small vouchers... It's really all those little efforts that makes it great, we like all that is around the box from the beginning to the end, there is really an effort of personalization from one month to the other. They make you participate, it's really great, and also products are great, there is no single product I'm not going to use in that box." (YTB1). To make up for the absence of online experiential content in e-commerce, MLB is creating a specific universe through a stimulating peripheral offer.

\section{Intrinsic Values}

The netnography also allowed collecting precise information about pre- and post-purchase behaviors. Regarding purchase motivations of MLB consumers, we identified a motivation linked to "play" and the fact of pleasing oneself. This is a purchase with a hedonic dimension that is more or less considered as a gift to reward or console oneself: "For all those who have a fucking life I recommend My Little Box because it's great..." (YTB1). YouTubers feel a compelling desire for the product that is linked to anticipation of emotions and feelings it will arouse. The desire is so intense that it leads some of them to mandatory live this moment before living it themselves: "I wanted to force myself not to watch any video about that box but I couldn't resist so I've watched one or two." (YTB5). The pleasure that is felt while watching the others' reviews is activated by cheerfulness and excitement: "What a pleasure and a laugh to see you. I must admit I've laughed a lot with your spray" (N.). This emotional quest for excitement translates into subscription to others offers, for men, pets or food. The beauty passionate transforms into a box fan and is looking again for the "first thrill" of discovering.

This purely hedonic aspect of the purchase may raise an "ethics" aspect in consumers, inducing guilt when taking the decision to purchase. Terms like "I gave in", "I couldn't resist" would match a fulfilled desire to the detriment of a more rational decision: "You make me laugh so much! This video is really interesting (...) and I think you make me feel like not resisting to My Little Box but I'll try to resist!!Mouahah^" (CM).

Another interesting element is the ritual character linked discovering MLB offer that can be seen in the unpacking videos. This ritual nature is contained and preprogrammed in the offer itself, thanks first to a very aesthetic packaging, a luxurious box designed by a well know drafstwoman, Kanako. Each month, the packaging related to the box theme (cocooning, Christmas, Valentine's Day) and content is packed with a small ribbon bow. Editorial elements and gifts are displayed in a specific order, creating a sprocess aiming at raising desire. It's a ritual programmed each month, highlighted by themes such as "As usual" that makes the individual participating by manipulating objects. Nothing is visible at first sight; products are enclosed in a bag, creating another discovering surprise. The nature of cosmetics products in itself appeals to senses such as touch, smell, sight and aesthetics. The peripheral offer is staged to reproduce shop stimuli and arouse pleasure for the consumer that sees his/her utilitarian values decreasing to the profit of this more hedonic activity. The consumer then alternates with surprise and the ritual equilibrating the experience and introducing reassuring anchor points as well as instability to keep senses on the alert. This ritual character sets up the "spiritual" aspect of this consumption experience. It is reinforced by some unique elements of the offer in itself: "There and then, they won my heart forever; there was that small card with words from John Mayor that is one of my favorite artists for those who know that." (YTB3). 


\section{CONCLUSION}

If we refer to testimonies integrated in this study, it is possible to analyze perceived value through the Holbrook (1999)'s typology. The following table summarizes those results.

Table 2. Holbrook (1999)'S Value Typology Applied To Beauty Boxes Reviews And Comments

\begin{tabular}{lll}
\hline & \multicolumn{1}{c}{ Extrinsic } & \multicolumn{1}{c}{ Intrinsic } \\
\cline { 2 - 3 } Self-oriented & $\begin{array}{l}\text { Efficiency } \\
\text { "You made me save a lot of money" } \\
\text { Excellence }\end{array}$ & Play \\
& "It's really all those little efforts that make it great" & "It's funny!" \\
\cline { 2 - 3 } & $\begin{array}{l}\text { Status } \\
\text { "I'll make you a review when I test the products." }\end{array}$ & "It smells good, it looks like a jewel" \\
Other-oriented & Esteem & "I gave in" \\
& "I got a product that everyone didn't get" & "I couldn't resist" \\
& & Spiritual value \\
\end{tabular}

The consumption experience of MLB is supplemented by a collective experience though exchanges between members of the community. The richer in emotions or information the review is, the more it will be visualized and commented. This social interaction gives the platform a certain status recognition, to the eyes of the community and to YouTube that pays channels making the highest traffic. There is then a social and economic dimension that goes beyond the individual consumption experience and enriches it of a posteriori meanings.

This exploratory research contributes to a developing understanding of a new consumption phenomenon, subscription-based e-commerce. If it is not a new business model, it goes beyond a mere economic purpose to become a real consumption phenomenon, associating curation and tryvertising on the firm's side and surprise, experience and a wide variety of values on the client's side. We've shown that this specific consumption entails all types of values that are traditionally identified in consumer behavior. These values are expressed and lived by clients and followers on social networks that get value from sharing as well as from a kind of mandatory consumption of the product. This research also contributes to consumer behavior by adopting netnography on videos and consumer comments, on a relatively wide sample and amount of data. Analyzing videos can bring valuable insights to consumer behavior study as textual, oral and behavioral data can be analyzed and associated.

One main limit of the study is the specificity of the area that was chosen (cosmetics) and the femaleexclusive sample. Regarding e-WOM, men could react and share differently, if communicating about more masculine products. Furthermore, others topics than values could have been deepened, especially surprise and emotional reactions. Research perspectives are numerous. Among them, studying more in details the effect of surprise and emotional reactions, both for clients and followers, should have priority. This study could also be replicated on more utilitarian products or other hedonic consumption areas.

\section{AUTHOR INFORMATION}

Mohamed Slim Ben Mimoun is an Associate Professor in Marketing at SKEMA Business School - Université de Lille and member of the M.E.R.C.U.R. research centre. His research focus on technologies and consumer behaviour. E-mail: $\underline{\text { m.slim_benmimoun@ @ skema.edu }}$

Marion Garnier is an Associate Professor in Marketing at SKEMA Business School - Université de Lille and member of the M.E.R.C.U.R. research centre. Her research focuses on consumption virtual experience, consumers'avatars, virtual objects purchase, as well as consumer behaviour on the Internet. E-mail: marion.garnier@skema.edu

Delphine Depledt is a web-marketing professional graduated from SKEMA Business School. E-mail: delphine.depledt@skema.edu 


\section{REFERENCES}

Bernard, Y. (2004). La netnographie : une nouvelle méthode d'enquête qualitative basée sur les communautés virtuelles de consommation. Décisions Marketing, 36, 49-62.

Babin, B. J., Darden, W.R. \& Griffin, M. (1994). Work and /or Fun: Measuring Hedonic and Utilitarian Shopping Value. Journal of Consumer Research, 20(4), 644-655.

Bickart, B. \& Schindler, R.M. (2001). Internet forums as influential sources of consumer Information. Journal of Interactive Marketing, 15(3), 31-40.

Cottet, P., Lichtlé, M-C. \& Plichon, V. (2006). The Role of Value in Services: A Study in a Retail Environment. Journal of Consumer Marketing, 23, 219-227.

Fong, J. \& Burton, S. (2008).A cross-cultural comparison of electronic word-of-mouth and country-of-origin effects. Journal of Business Research, 61(3), 233-242.

Goldsmith, R.E. (2006). Electronic Word-of-Mouth. In Encyclopedia of E-Commerce, E-Government and Mobile Commerce, Mehdi Khosrow-Pour (Ed.), Idea Group Publishing, 408-412.

Holbrook, M. (1999). Consumer Value. A framework for analysis and research, Coll. Routledge Interpretive Marketing Research, London and New York: Routledge.

Holbrook, M. \& Hirschman, E.C. (1982). The Experiential Aspects of Consumption: Consumer Fantasies, Feelings and Fun. Journal of Consumer Research, 9(2), 132-140.

Holt, D.B. (1995). How Consumers Consume: A Typology of Consumption Practices. Journal of Consumer Research, 22(1), 1-16.

Khammash, M. \& Griffiths, G.H. (2011). Arrivederci CIAO.com, Buongiorno Bing.com - Electronic word-of-mouth (eWOM), antecedences and consequences. International Journal of Information Management, 31(1), 8287.

Kozinets, R.V. (1997). I want to believe: a netnography of the X-philes' subculture of consumption. in Advances in Consumer Research, Volume 24, eds. Merrie Brucks and Deborah J. MacInnis, Provo, UT : Association for Consumer Research, 470-475.

Kozinets, R.V. (1999), E-tribalized marketing? The strategic implications of virtual communities of consumption. European Journal of Management, 17(3), 252-264.

Kozinets, R.V., Sherry, J.F., DeBerry-Spence, B., Duhachek, A., Nuttavuthisit, K. \& Storm D. (2002). Themed Flagship Brand Stores in the New Millennium: Theory, Practice, Prospects. Journal of Retailing, 78(Spring), 17-29.

Kozinets, R.V. (2002). The Field Behind the Screen: Using Netnography for Marketing Research in Online Communities. Journal of Marketing Research, February, 61-72.

Kozinets, R.V. (2010). Netnography: The marketer's secret weapon, How social Media Understanding Drives Innovation. NETBASE Publication.

Lee, J., Park, D-H. \& Han, I. (2008). The effect of negative online consumer reviews on product attitude: An information processing view. Electronic Commerce Research and Applications, 7(3), 341.

Michon, R. \& Chebat J-C. (2004). Cross-Cultural Mall Shopping Values and Habitats A Comparison between English- and French-Speaking Canadians. Journal of Business Research, 57(8), 883- 892.

Mumaw, S. (2011). Chasing the Monster Idea: the marketer's almanac for predicting idea epicness, NJ: John Wiley $\&$ Sons.

Rosenbaum, S. (2011). Curation Nation: How to Win in a World Where Consumers are Creators, US: MacGrawHill.

Ratchford, B.T., Lee M-S. \& Talukdar D. (2003). The impact of the Internet on information search for automobiles. Journal of Marketing Research, 40(May), 193-209.

Vanhamme, J. \& Snelders D. (2003).What If You Surprise Your Customers ... Will They Be More Satisfied? Findings From A Pilot Experiment. in Advances in Consumer Research Volume 30, eds. Punam Anand Keller and Dennis W. Rook, Advances in Consumer Research Volume 30: Association for Consumer Research, 48-55. 